Article

\title{
Equipment Development for Small and Urban Conservation Farming Systems
}

\author{
Ted S. Kornecki ${ }^{1, *}$ and Manuel R. Reyes ${ }^{2}$ \\ 1 USDA-ARS, National Soil Dynamics Laboratory, Auburn, AL 36832, USA \\ 2 Sustainable Intensification Innovation Lab, Kansas State University, Manhattan, KS 66506, USA; \\ mannyreyes@ksu.edu \\ * Correspondence: ted.kornecki@usda.gov; Tel.: +1-334-887-8596
}

Received: 1 October 2020; Accepted: 26 November 2020; Published: 2 December 2020

\begin{abstract}
The number of local small farms in the USA is on the rise due to a consumer demand for locally grown produce such as tomatoes. These farms often use small walk-behind tractors, but most field activities are still performed by hand requiring heavy physical labor. Recent efforts from USDA have been encouraging producers to adopt no-till techniques using cover crops for benefits such as reduced runoff and soil erosion, increased infiltration and water holding capacity, increased soil organic carbon, decreased soil compaction and improved weed control. However, lack of specialized no-till equipment inhibits widespread adoption of cover crops. To help small farms reduce hand labor and adoption of conservation systems with cover crops, no-till equipment such as a no-till drill, powered roller/crimper, and no-till transplanter have been developed for walk-behind tractors at the National Soil Dynamics Laboratory in Auburn (AL, USA). A replicated three-year field test (2017-2019) was conducted to evaluate effectiveness of the experimental powered coulter drill to plant cereal rye cover crop (Secale cereale, L.), patented powered roller/crimper to terminate rye, and transplanting cash crop tomato (Solanum lycopersicum L.) seedlings with a patented no-till transplanter. These three pieces of equipment were compatible with BCS 853 walk-behind tractor. The experiment was conducted on two different soils: Hiwassee sandy loam soil and Davidson clay to determine the performance of developed machines under different soil types. Results have shown that the powered coulter drill generated effective rye seed emergence $(83 \%)$ for optimum biomass production. The experimental powered roller/crimper generated $95 \%$ rye termination rate three weeks after rolling, and the no-till transplanter performed as anticipated providing less than $10 \%$ variation of plant spacing uniformity. Tomato yield varied among years ranging from $15.9 \mathrm{Mg} \mathrm{ha}^{-1}$ to $28.3 \mathrm{Mg} \mathrm{ha}^{-1}$ and was related to different soil and weather conditions at each growing season. Numerically higher tomato yield on Davidson clay might be associated with less insect/pathogen pressure, higher plant available water, and reduced weed pressure due to greater cereal rye biomass production. Results from this experiment indicate that developed experimental equipment can be a practical solution for small no-till farming operations with cover crops.
\end{abstract}

Keywords: roller/crimper; no-till drill; no-till transplanter; walk-behind tractor; cover crop; tomato seedlings

\section{Introduction}

The number of local urban farms producing fruit and vegetables for local farmers' markets the in USA is on the rise. This increase is driven by consumer demand for healthy and fresh locally grown produce. Local farms usually own small walk-behind tractors with interchangeable attachments. Majority of these small farms realize benefits of utilizing cover crops which are widely promoted by USDA ARS and NRCS to increase sustainability of agriculture production. According to Reeves [1], 
these multiple benefits that cover crops can provide include weed suppression due to mulching and allelopathic effects, increased water infiltration and water holding capacity, increased soil organic carbon, reduced soil erosion, runoff, and soil compaction. To optimize these benefits, cover crops must be terminated at the appropriate growth stage and managed appropriately, which involves flattening down and crimping with rollers/crimpers as a preferred method of mechanical termination [2,3]. Cover crops must be terminated at an appropriate growth stage to optimize biomass production and to create mulch through which cash crops can be planted directly into cover crop residue $[4,5]$. A roller/crimper flattens a living plant, and crimping bars (equally spaced on the roller's drum) crimp stems, crushing them to enhance desiccation. Desiccated residue forms a thick layer of mulch on the topsoil to protect soil surface from harmful rainfall energy, thus reduces soil erosion, and runoff, reduces weed germination and growth, and conserves water for the subsequent cash crop [6]. In the southern US, mechanical termination of cover crop should be done at least 3 weeks before planting a cash crop into flatten residue to minimize a competition for soil moisture and nutrients [7]. A typical cover crop grown in the Southern US is cereal rye (Secale cereale L.), and can produce between 3 to 11 metric $\mathrm{Mg}$ per ha of biomass providing benefits such as allelopathic weed suppression and a mulch effect due to improved soil surface cover [8]. According to Ashford and Reeves [4] rye termination rates above $90 \%$ were sufficient to plant a cash crop into desiccated residue without competing for resources. Common practice in accelerating termination process is to utilize herbicides (glyphosate: Roundup $^{\mathrm{TM}}$ ) as a supplement to rolling/crimping. This practice, however, is not permitted in organic systems, where the use of commercial herbicides is prohibited. Because of this restriction mechanical termination by rollers/crimpers must be as effective as chemical application.

A limiting factor to widely utilize cover crops is the lack of commercially available equipment (rollers/crimpers) needed to manage tall cover crops such as cereal rye, planting, and transplanting equipment compatible with walk behind tractors. In addition, the tradition of tilling soil in vegetable production is strong in this region. For example, conventional tomato production traditionally involves deep tillage and bedded plastic mulch to minimize weed populations. Conventional tillage, however, causes increased soil erosion and nutrient loss, increases soil strength and depletes soil organic carbon content [9,10]. Abdul-Baki et al. [11] who studied tomato production under no-till hairy vetch mulch, indicated that no-till tomato yield was like conventional systems, and provided more uniform yield throughout the growing season. Edralin et al. [12] in a study at Siem Reap, Cambodia, found average yield of tomato, cucumber, round eggplant, yard long bean and cabbage, were higher and weed pressure lower in conservation agriculture no-till and mulched based production system compared with conventional tilled production system. Assefa et al. [13] in a study conducted in Sub-Saharan Africa (Ethiopia and Ghana), measured substantial increases in yields of garlic, onion, cabbage tomato and sweet potato with decreases in water use in conservation agriculture no-till mulched based systems compared with conventional tilled production system. Lastly, Paudel et al. [14] measured, under conservation agriculture no-till mulched based plus integrated pest management practices versus traditional farmer practices; yields, benefit-cost ratios, labor requirements, insect and disease infestations in four different locations in Nepal and found tomatoes, cucumbers, and bitter gourds, produced significantly higher yields, greater benefit-cost ratios, reduced labor, and decreased the infestation of pests and diseases. Therefore, no-till vegetable production with cover crops might be a good solution to protect the soil and the environment while decreasing vegetable production costs and water use. Moreover, in recent years there is an increased interest by small farms (with less than one hectare of cultivated land), in utilizing cover crops in no-till vegetable systems to reduce cost of inputs (fuel and labor) and protect soil, while maintaining or increasing cash crop yields. Traditional equipment such as rollers/crimpers, no-till drills, and transplanters are intended for larger farms that rely on larger tractors. However, the use of bigger and powerful tractors is impractical on small vegetable farms and might be too heavy for the available power source and too large for the narrow beds that are typical for smaller vegetable farms. On these farms, tractors are usually 
small and less powerful compared to large farms because of cost. Walk-behind tractors are a popular, cost-effective choice, and are typically used for everyday small farm operations (Kornecki, [15]).

Walk behind tractors that are already on the market do not have any availability of specialized no-till attachments except for basic tillage, mulching and mowing tools. To address the needs associated with sustainable agriculture on small local farms, a set of no-till equipment such as active coulter drill, powered roller/crimper, and no-till transplanter were developed for a self-propelled walk-behind tractors that allows small producers to effectively plant and terminate their cover crops (i.e., cereal rye), and transplant cash crop (i.e., tomato) directly into flatten residue of cover crop, in order to reduce manual labor while increasing efficiency of field activities.

The powered coulter no-till drill, which was designed specifically for walk behind tractors, does not exist on the market, especially for this scale of equipment. In addition, a no-till transplanter does not exist for a walk behind tractor that is designed for no-till planting into cover crop residue. The patented powered roller/crimper was evaluated together with the no-till drill and transplanter as one no-till systems approach to plant and manage cover crops at their optimum biomass production, and transplant vegetable seedlings into a previously flattened and terminated cover crop residue.

The objective of this field experiment was to evaluate the performance (mechanical) and quality (agronomic) of experimental no-till equipment developed for a BCS 853 walk-behind tractor: (1) active Coulter drill to plant a cereal rye cover crop; (2) a patented powered roller/crimper to terminate cereal rye, and (3) The no-till transplanter by planting tomato seedlings into flattened rye residue cover.

\section{Materials and Methods}

A replicated field experiment (a completely randomized design with 3 replications) was initiated in the fall of 2016 on a Hiwassee sandy loam and Davidson clay soils by planting a cereal rye cover crop Figure 1 using a modified powered coulter no-till drill (Patent application [16]; Figure 2). A patented powered roller/crimper for a walk behind tractor ([17]; Figure 3) was used to terminate cereal rye at the early milk growth stage, and a patented no-till transplanter [18] depicted in Figure 4A was used to transplant tomato seedlings (Lycopersicon esculentum L.) into the rolled rye cover. A row of transplanted tomato plants placed by the no-till transplanter into rolled cereal rye residue is shown in Figure 4B. Transplanting seedlings was evaluated on rolled plots only, as transplanting into standing cover crop is not standard operation in no-till systems. The untreated standing cereal rye was used as the baseline for comparing termination rates and volumetric soil moisture content (VMC) with residue flattened and crimped by the powered roller/crimper. Control plots were not used to transplant tomato seedlings into standing cereal rye due to increased residue interference with the transplanter. These devices were compatible with an Italian BCS 853 walk-behind tractor weighing $111 \mathrm{~kg}$ with a one-cylinder 9.7 KW gasoline engine. 


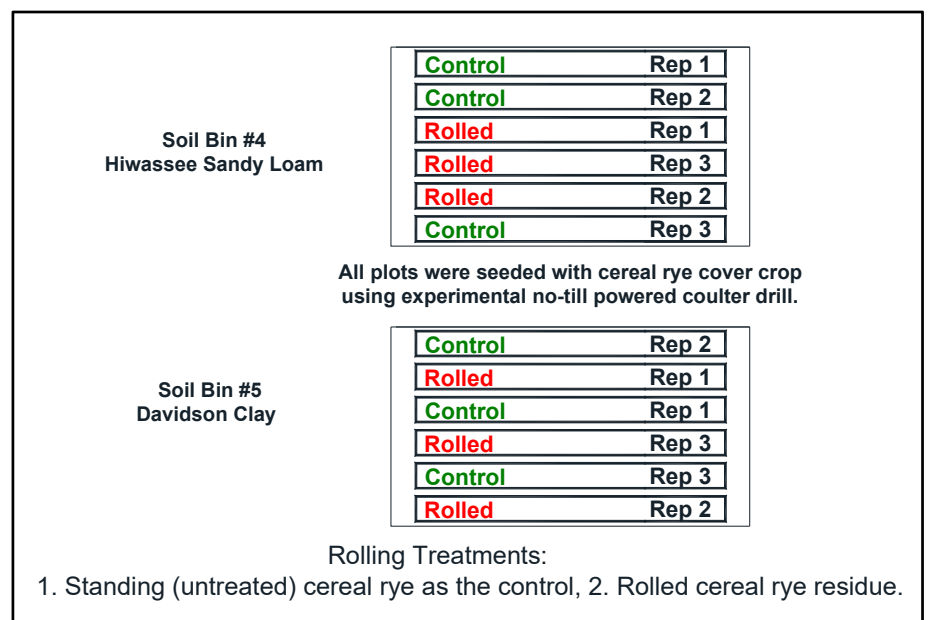

Figure 1. Experimental layout to evaluate performance of no-till equipment for walk behind tractor: 1. Powered coulter no-till drill to plant cereal rye cover crop, 2. Powered roller/crimper to roll down and crimp cover crop, 3. No-till transplanter to transplant seedlings (tomato) only into rolled and desiccated cereal rye residue. There was no transplanting tomato into the control plots as this practice is not a standard agronomic operation for a no-till system with cover crops.

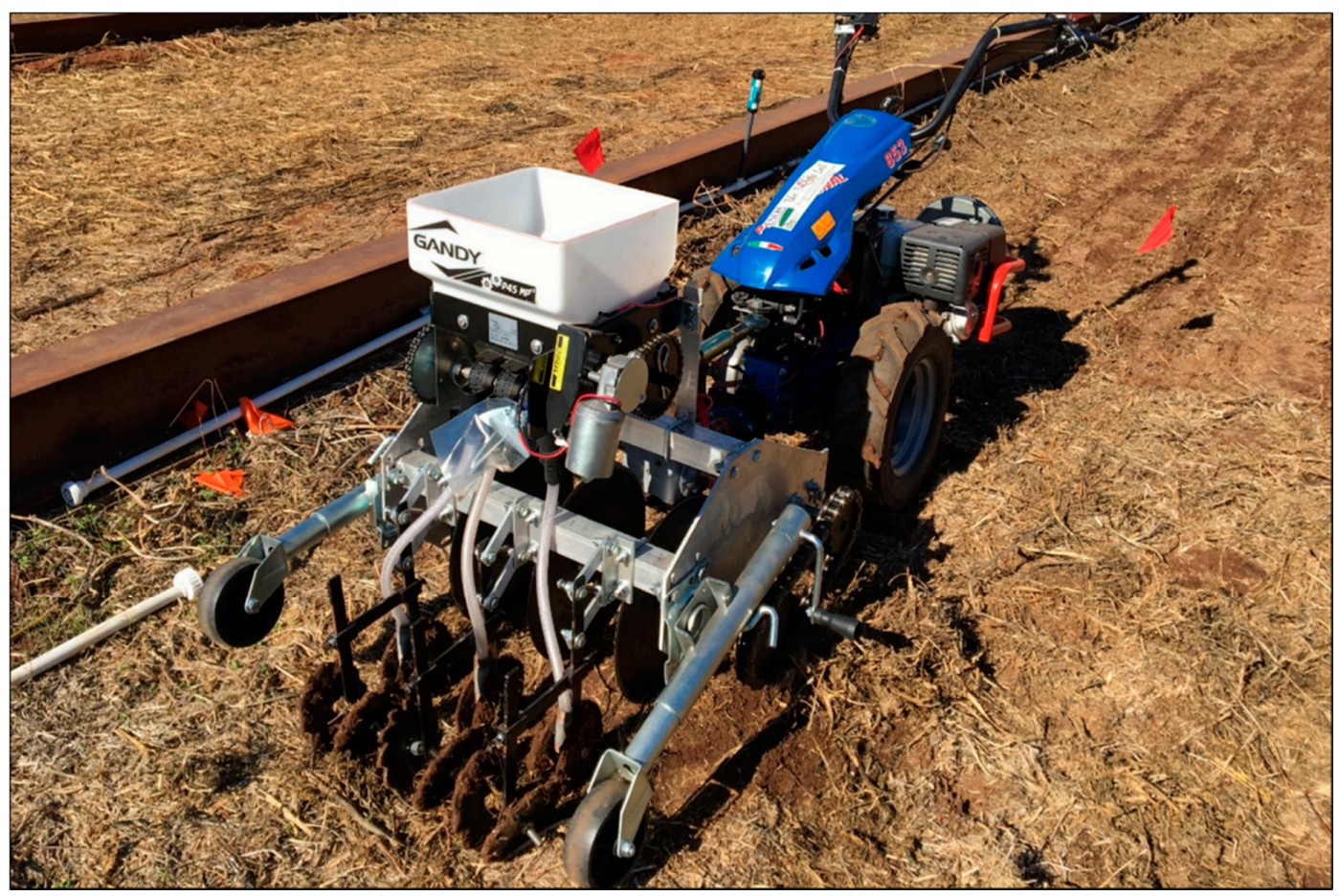

Figure 2. Powered active coulter no-till drill (working width: $0.6 \mathrm{~m}$, spacing between coulters $0.2 \mathrm{~m}$, weight: $120 \mathrm{~kg}$ ) for a BCS 853 Tractor [14]; patent application \#14501594). 


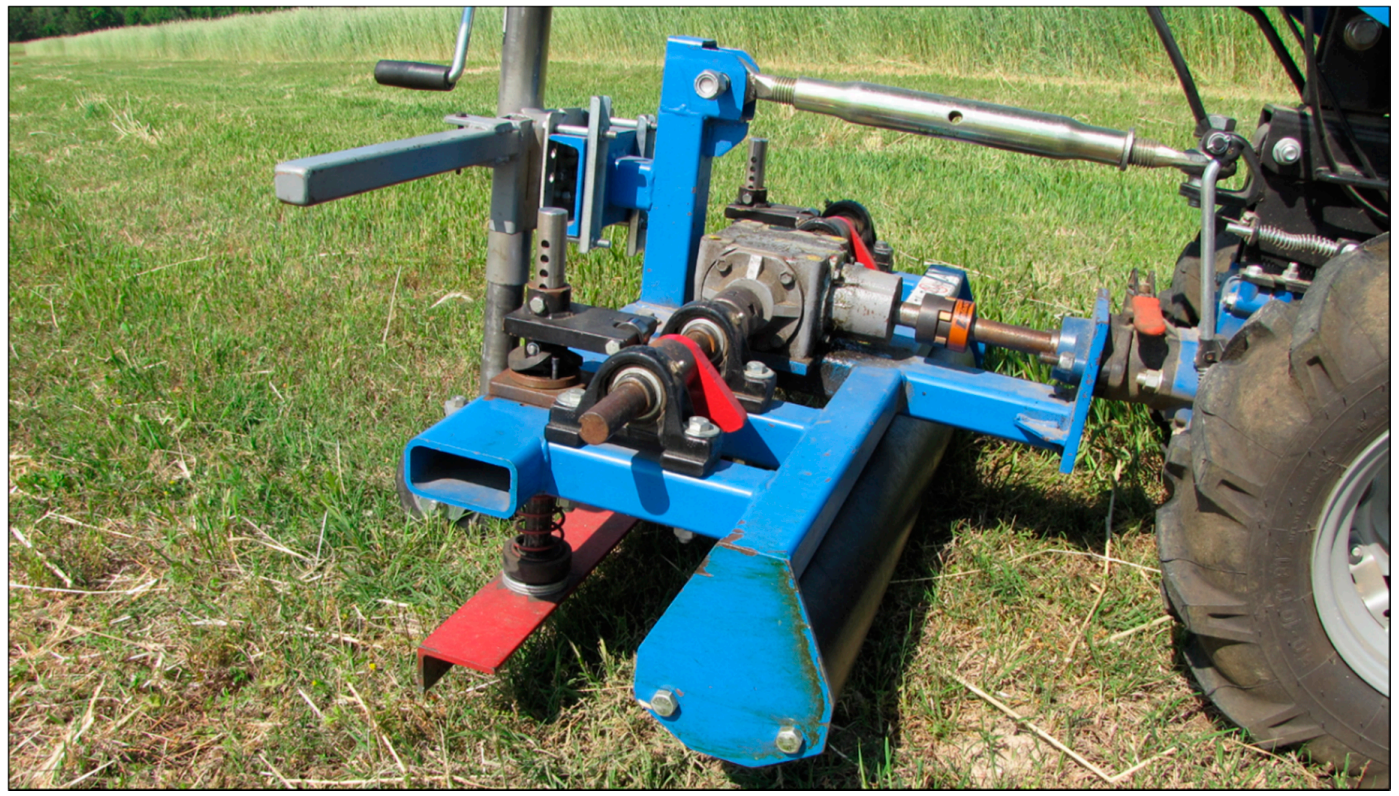

Figure 3. Side view of the powered roller/crimper with crimping bar (red color) weighting $86 \mathrm{~kg}$, preloaded with two compression springs [17]; US patent \# 7,987,917 B1.

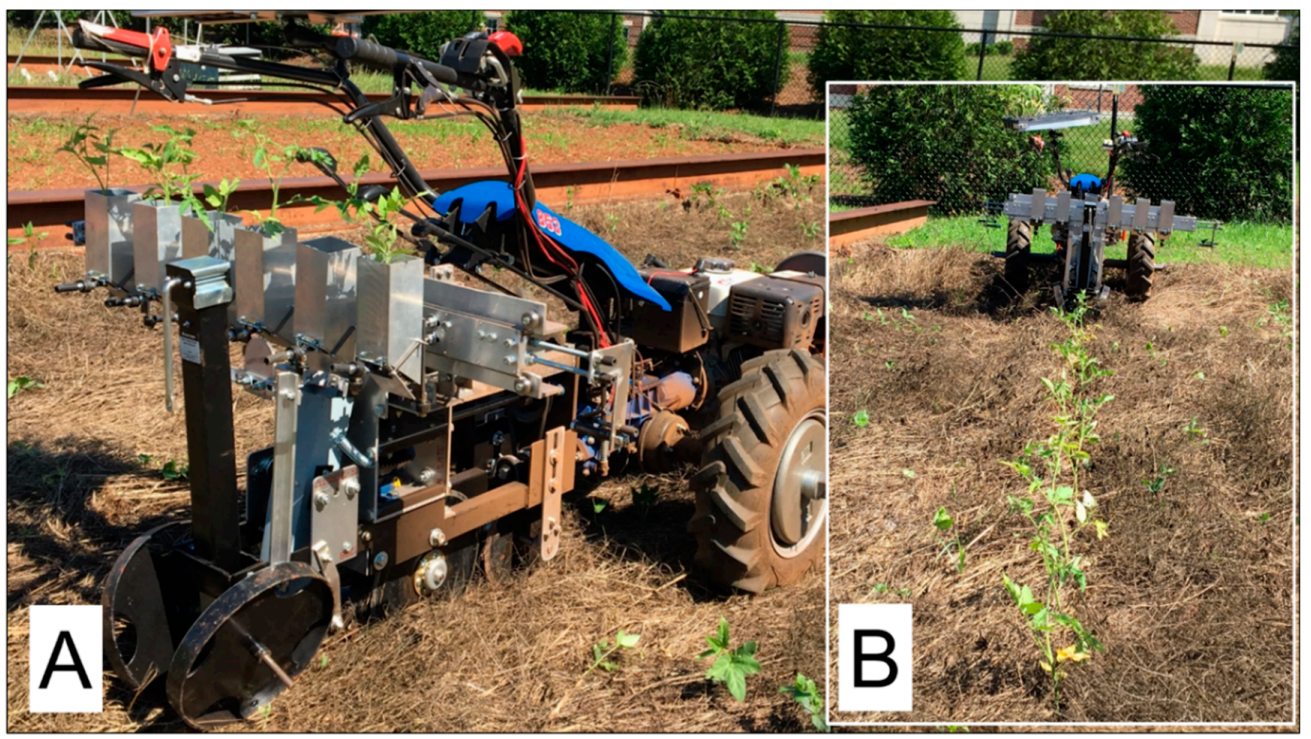

Figure 4. (A) no-till transplanter weighting $125 \mathrm{~kg}$ for the walk behind tractor [16]. US patent number: US 10,004,174 B2). (B) Transplanted tomatoes into rolled and crimped cereal rye residue cover.

\subsection{Equipment}

\subsubsection{No-Till Powered Coulter Drill}

Because of weight restriction, the planter's enhanced design is required to successfully plant seeds into soil with residue cover using small low-power walk-behind tractors. These tractors must provide power (through the PTO shaft) to rotate cutting units (coulters) at RPMs higher than through rotation provided by friction to cut the residue and make a notch for appropriate depth seed placement. This solution allowed soil penetration due to rotating (higher RPM) coulters at the desired depth compensating for the low weight of the planter $(120 \mathrm{~kg}) ; 40 \mathrm{~kg}$ per one planting unit [14]. The primary components of the no-till planter were three active $0.38 \mathrm{~m}$ diameter coulters (active: means powered from the tractor's PTO (Figure 2). In this planting system, the tractor's PTO connection rotates at 
approximately 940 RPM is connected to a reduction 90-degree gearbox with 2:1 ratio. From there, the gearbox outputs at a speed of 470 RPM that is coupled to a chain drive (1.3:1 ratio) providing power to a keyed shaft on which the individual coulters are mounted with a final rotational speed of 360 RPM. The seed hopper capacity was $0.021 \mathrm{~m}^{3}$. Metering units placed at the hopper's bottom are operating independently from the powered coulter and tractor operating speed, utilizing the 12-volt electric motor with a built-in reduction gear box from the commercially available vendor GANDY ${ }^{\mathrm{TM}}$. Therefore, constant operating must be maintained to obtain a constant seeding rate on which the machine was calibrated. Seed falls through a flexible tube connected to the metering unit each with a set double disk opener for seed placement at the desired depth. Behind the disk openers there are the closing press wheels to close the grooves and to make sufficient seed to soil contact. A spring-loaded parallel linkage system provides flotation and downforce to each independent row unit.

\subsubsection{Powered Roller/Crimper}

The roller/crimper is a PTO-driven unit that is attached to the self-propelled walk-behind tractor. The roller/crimper includes a smooth cylindrical steel drum behind which is a crimping bar assembly comprised of a crimping bar connected to two vertical shafts with compression springs and lifters mounted on these shafts. A PTO-driven reduction gearbox assembly with a 2:1 ratio provides rotation at 420 RPM to two camshafts on either side of the gearbox which engage with the lifters (Figure 3). The working width of the roller/crimper is $0.9 \mathrm{~m}$. When engaged with the two camshaft assemblies, the lifters provide one lift per revolution. At 420 RPM the crimping frequency to flattened cover crop is 7 crimps per one second. During lifting, the two springs are compressed against the roller's frame and the crimping bar assembly. When released, the springs provide downward force and rapid vertical movement to the crimping bar assembly. During operation, the smooth cylindrical drum first flattens the cover crop in the direction of the tractor's travel, and then the crimping bar assembly crimps the cover crop due to its downward acceleration from the decompressing springs after cams disengage from the crimping bar lifters. The roller consists of a $20.2 \mathrm{~cm}$ diameter steel drum with a $2.54 \mathrm{~cm}$ diameter shaft protruding from each side and supported by pillow bearings attached to the main frame. A reduction gearbox is mounted on the center of the frame and positioned for proper axial engagement with the PTO shaft [17].

\subsubsection{No-Till Transplanter for Walk behind Tractor}

Larger commercial transplanters must be operated by at least two people; one to ride the transplanter and one person to drive the tractor. In contrast, this system is operated by one person who simultaneously operates the walk-behind tractor (Figure 4). The transplanter comprises six vertical assemblies of rectangular tubes for seedlings, which are continuously moving from left to the right transversely to the driving direction. The main assemblies and mechanisms of the no-till transplanter are depicted in Figure 5. 


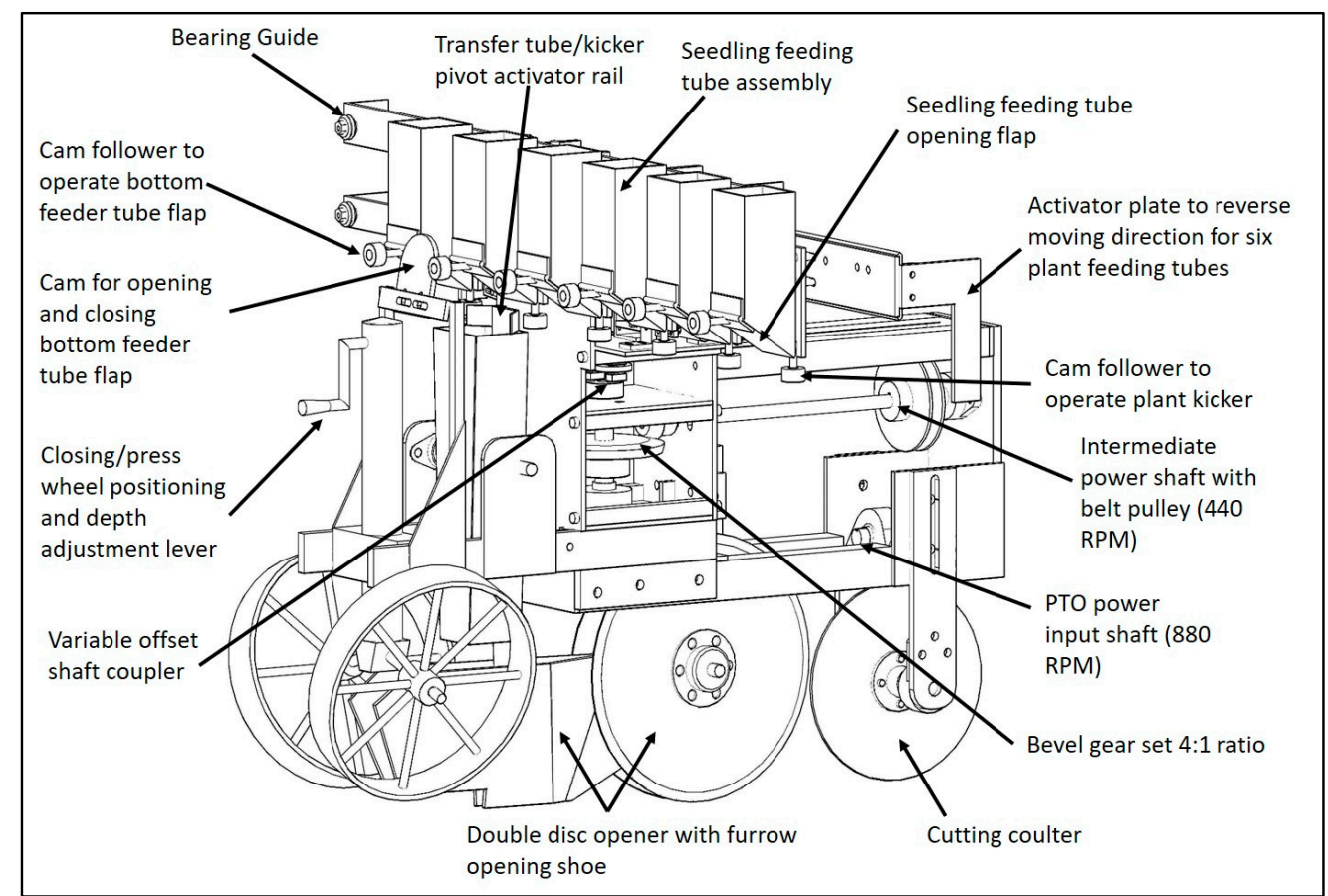

Figure 5. Main components of no-till transplanter for the walk behind tractor with functional description of each mechanism.

Direction changes for the tube assembly are controlled by a unique reversing mechanism, so vegetable seedlings can be supplied from both sides of the row while walking. Vegetable trays can be positioned on both sides of the transplanter for better stability of the unit. To energize the transplanting unit, a PTO provides a rotational speed of 880 RPM, which is then reduced to 440 RPM using a belt drive with a 2:1 reduction. The upper horizontal shaft with the larger pulley rotating at $440 \mathrm{RPM}$ is connected to the vertical shaft by two perpendicular bevel gears with a ratio of 4:1 causing the vertical shaft to rotate at 110 RPM. A rack and pinion mechanism are utilized to move the seedling tray in the left and right directions in a typewriter-type motion. Automatic direction changes are achieved using a drive gear mounted to a drive shaft that rotates within a sleeve. The sleeve has two shafts mounted to it that protrude perpendicularly which slide in linear bearings, thus allowing the drive shaft in the sleeve that is coupled to the lower drive unit via an offset bearing (flexible coupling) to move in the left and right direction when pushed. The perpendicular shafts have a locking pin that engages with a spring-latch assembly allowing the gear to mesh with the final drive until the assembly is triggered by a spring-loaded pusher to unlock and shift to the other side, thus reversing direction. The drive gear that is mounted to the slidable shaft engages with the final drive gear that is two times its diameter thus achieving a 2:1 reduction which is $55 \mathrm{rpm}$ at the final drive. This propels the rack at linear speed of $0.08 \mathrm{~m} / \mathrm{s}$ in both directions. The tubes that are attached to the rack hold the seedling until the bottom spring-loaded door is opened by a cam follower triggered by a stationary cam allowing the seedlings to fall by gravity into the kicker chamber. The spring-loaded kicker positions the plant in the furrow previously opened by the no-till disc coulter and double disk openers. The two closing wheels press the sides of the furrow to the plant to provide sufficient root to soil contact for optimum growth.

\subsection{Procedures}

Each fall (2016-2018), cereal rye was planted at rate of $101 \mathrm{~kg} \mathrm{ha}^{-1}$ utilizing an experimental active coulter drill (Figure 1). After a visible emergence of cereal rye plants, the number of plants was counted to determine planting effectiveness by this experimental drill. In each spring (2017-2019 growing seasons for tomatoes) before rolling/crimping of cereal rye, biomass samples were collected $\left(0.5 \mathrm{~m}^{2}\right.$ sample area) and were oven-dried using a programmable electric shelf oven, Model No. SC-400 [19] 
with forced convection air flow for $72 \mathrm{~h}$ at temperature set to $55^{\circ} \mathrm{C}$ (Grieve Corporation, Round Lake, IL, USA) to estimate the amount of dry biomass produced in each plot. Also, height (randomly selected 10 counts per plot) of rye was recorded. At both soil types, cereal rye was rolled/crimped in the early milk growth stage (Zadoks scale: \#73; [20]), which is a desirable growth stage for termination that typically produces an optimum level of biomass [2]. Cereal rye termination data were collected during the three weeks after the termination. During this time of evaluation, volumetric soil moisture content (VMC) was also measured. Results were compared to standing (untreated) cereal rye cover crop. Rye termination was estimated using a handheld light sensor chlorophyll meter SPAD 502 (Konica-Minolta, Ramsey, NJ, USA). This portable sensor is capable of instantly measuring the chlorophyll content or "greenness" of plants. The SPAD 502 quantifies slight changes or trends in plant health long before they are visible to the human eye and provides a non-invasive measurement. The meter was clamped over leafy tissue, and an indexed chlorophyll content reading (usually from 0 to 50.00 ) is recorded in less than $2 \mathrm{~s}$. The data logging version of the SPAD 502 (item 2900DL) allowed for easier compiling of readings for statistical analysis. Since the state of the plant greenness is related to chlorophyll activity (e.g., $\geq 50$ for healthy plants, and 0 for a dead plant with no chlorophyll activity), this concept was used to detect different stages of cover crop termination due to plant senescence from injury caused by mechanical termination using roller/crimpers. To obtain a reading for each plot, five readings of plant tissue were collected in each plot by manually clamping the chlorophyll meter on randomly selected plants and storing the readings in the data logger. These five readings were averaged for each plot. Cereal rye termination rates on a scale of $0 \%$ (no injury symptoms) to $100 \%$ (complete death of all plants) were based on a procedure described in Kornecki et al. [21]. Evaluation was performed 7, 14, and 21 days after the rolling treatments. Percentages of cover crop termination rates were transformed using an arcsine square root transformation method [22], but this transformation did not result in a change in the analysis of variance (ANOVA), thus, non-transformed means are presented. Similarly, volumetric moisture content (VMC in \%) was measured (5 readings per each plot and averaged) at 7 , 14, and 21 days after rolling treatment application using a portable TDR 300 moisture meter with $0.12 \mathrm{~m}$ long rods from Spectrum Technologies* (Plainfield, IL, USA). Selection of $0.12 \mathrm{~m}$ long stainless-steel rods was based on a need of determining volumetric moisture content (VMC) and water availability for tomato plants after transplanting at the root zone ( $\sim 0.06 \mathrm{~m}$ depth). Three weeks after cereal rye termination, tomatoes (cultivar Amelia) were transplanted directly into cover crop residue utilizing the patented no-till vegetable transplanter for walk behind tractors. Data were analyzed by analysis of variance and treatment means were separated using the Fisher's protected Least significant differences (LSD) test at the $10 \%$ probability level. Cover and no-till equipment were considered fixed effects and years were considered random effects [23]. Where interactions between treatments and weeks or years occurred, data were analyzed separately and where no interactions were present, data were combined using SAS [24] ANOVA Analyst's linear model.

\section{Results and Discussion}

\subsection{Cereal Rye, Height, Biomass and Planting Efficiency}

Statistical results (ANOVA) indicate that for dependent variables: cereal rye heigh and biomass indicate that there was significant difference in cereal rye biomass with respect to factors YEAR and SOIL (Table 1). In contrast, planting efficiency for cereal rye was not significantly different for these factors. 
Table 1. Analysis of variance results for cereal rye planting efficiency and its height and the biomass.

\begin{tabular}{cccccccc}
\hline \multirow{2}{*}{ Source } & $*$ & \multicolumn{2}{c}{ Cereal Rye Plant Height } & \multicolumn{2}{c}{ Cereal Rye Biomass } & \multicolumn{2}{c}{$\begin{array}{c}\text { Planting Efficiency for } \\
\text { Cereal Rye }\end{array}$} \\
\cline { 3 - 8 } & & $p$-Value & $\mathbf{P r}>\mathbf{F}$ & $\boldsymbol{p}$-Value & $\mathbf{P r}>\mathbf{F}$ & $\boldsymbol{p}$-Value & $\operatorname{Pr}>\mathbf{P}$ \\
\hline YEAR & 2 & 20.07 & 0.0003 & 22.82 & 0.0002 & 1.42 & 0.2863 \\
BLOCK & 2 & 2.45 & 0.1366 & 0.70 & 0.5187 & 0.53 & 0.6038 \\
SOIL & 1 & 6.50 & 0.0289 & 29.27 & 0.0003 & 0.98 & 0.3465 \\
\hline
\end{tabular}

${ }^{*}$ DF (Degrees of Freedom).

Based on $101 \mathrm{~kg} \mathrm{ha}^{-1}$ seeding rate for cereal rye, the nominal number of seed per $1.0 \mathrm{~m}^{2}$ is 595 . Number of rye plants per $1.0 \mathrm{~m}^{2}$ area for Davidson clay ranged from 473 to 493 plants, whereas sandy loam number of plants were from 461 to 525 . An average percentage of emerged seeds over the three growing seasons was $81.7 \%$ and $84.3 \%$ for Davidson clay and Hiwassee sandy loam, respectively (Table 2).

Cereal rye planting emergence as depicted in Figure 6A, showed a uniform greenness without skips indicating that powered coulter drill planted cereal rye seeds uniformly. Moreover, the number of emerged plants per $1.0 \mathrm{~m}^{2}$ area indicate that the active coulter no-till drill performed as well as standard heavy no-till drills. In 2017, rye biomass production on Davidson clay was $9.8 \mathrm{Mg} \mathrm{ha}^{-1}$, with plant height of $159 \mathrm{~cm}$, whereas on sandy loam rye biomass was significantly lower generating $4.9 \mathrm{Mg} \mathrm{ha}^{-1}$ and plant height $149 \mathrm{~cm}$ which is a typical rye biomass generated by commercial heavy no-till drills. In 2018 rye biomass production was similar on both soils generating $11.4 \mathrm{mg} \mathrm{ha}^{-1}(162 \mathrm{~cm}$ height) on Davidson clay and $11.2 \mathrm{Mg} \mathrm{ha}^{-1}$ (156 cm height) on Hiwassee sandy loam. In 2019 growing season, rye biomass was higher on Davidson clay producing $9.4 \mathrm{Mg} \mathrm{ha}^{-1}$ (height $166 \mathrm{~cm}$ ) compared to $5.9 \mathrm{Mg} \mathrm{ha}{ }^{-1}$ with plant height of $168 \mathrm{~cm}$ on sandy loam. Main reason for differences in biomass production was for the clay soil availability to hold nutrients and water better during the rye growing season compared to sandy loam, where more infiltration might cause leaching of nutrients.
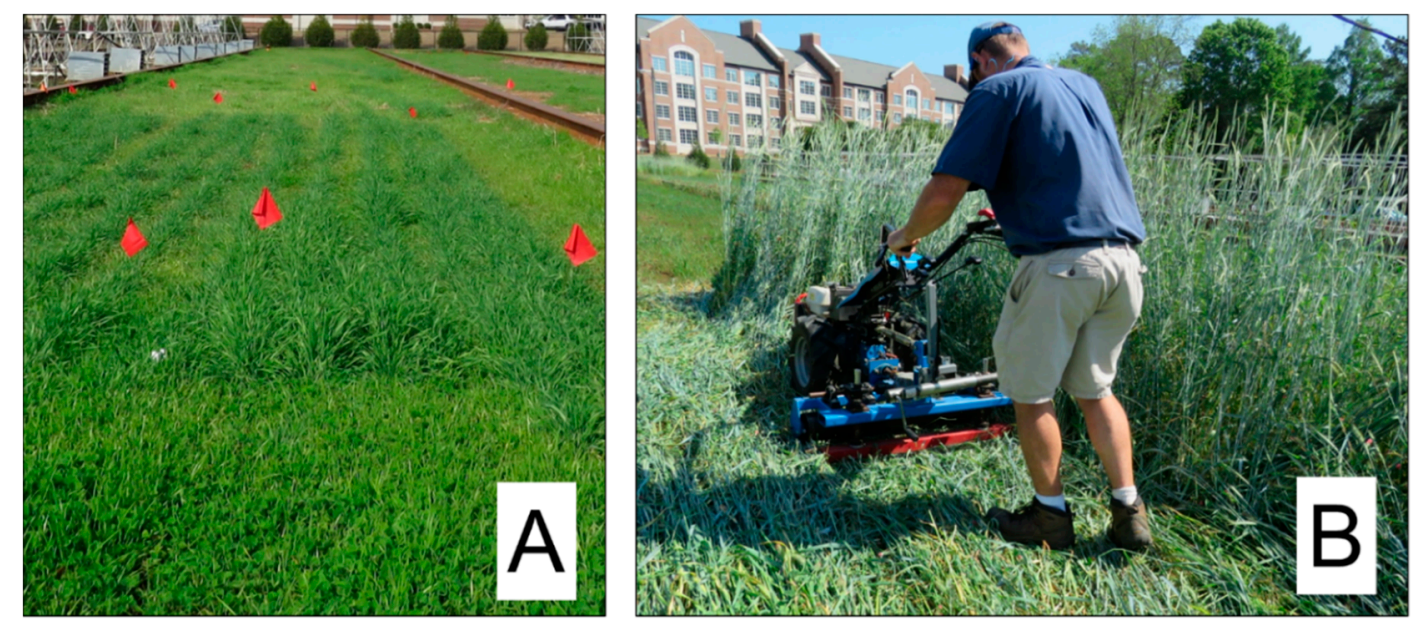

Figure 6. (A) Cereal rye stands in early spring planted with the powered coulter drill as shown in Figure 1. (B) Rolling/crimping cereal rye (at milk growth stage) using a powered experimental roller/crimper [15], US patent \# 7,987,917 B1) as shown in Figure 2. 
Table 2. Cereal rye height, biomass, and number of plants per $1.0 \mathrm{~m}^{2}$ and powered coulter drill planting efficiency for Davidson clay and Hiwassee sandy loam soils.

\begin{tabular}{|c|c|c|c|c|c|c|c|c|}
\hline \multirow{3}{*}{ Growing Season } & \multicolumn{8}{|c|}{ Soil Type } \\
\hline & \multicolumn{4}{|c|}{ Davidson Clay } & \multicolumn{4}{|c|}{ Hiwassee Sandy Loam } \\
\hline & Height Plant (cm) & Rye Biomass $\mathrm{Mg} \mathrm{ha}^{-1}$ & $\begin{array}{l}\text { Number of Rye } \\
\text { Plants/ } \text { m }^{2}\end{array}$ & * Planting Efficiency (\%) & $\begin{array}{c}\text { Height } \\
\text { Plant }(\mathrm{cm})\end{array}$ & $\begin{array}{l}\text { Rye Biomass } \\
\text { Mg ha }^{-1}\end{array}$ & $\begin{array}{c}\text { Number of } \\
\text { Rye Plants } / \mathrm{m}^{2}\end{array}$ & Planting Efficiency (\%) \\
\hline 2017 & 159 & 9.8 & 493 & 82.9 & $149 c^{* *}$ & $4.9 \mathrm{~b}$ & 461 & 77.5 \\
\hline 2018 & 162 & 11.4 & 473 & 79.5 & $156 \mathrm{~b}$ & $11.2 \mathrm{a}$ & 519 & 87.2 \\
\hline 2019 & 166 & 9.4 & 492 & 82.7 & $168 \mathrm{a}$ & $5.9 \mathrm{~b}$ & 525 & 88.2 \\
\hline$p$-Value & 0.2177 & 0.2255 & 0.7572 & 0.7572 & 0.0019 & 0.0035 & 0.1023 & 0.1023 \\
\hline LSD & N/A & N/A & N/A & N/A & 4.5 & 1.8 & N/A & N/A \\
\hline
\end{tabular}

* Nominal number of seeds per $1.0 \mathrm{~m}^{2}$ area $=595$ weighting $10 \mathrm{~g}(0.01 \mathrm{~kg})$ seeds based on $101 \mathrm{~kg} \mathrm{ha}^{-1}$ seeding rate. ** Treatment means followed by the same lowercase letters within each column for each soil type are not significantly different according to Fisher's Least Significant Difference Test $(\alpha=0.10)$ 


\subsection{Cereal Rye Termination Rates}

ANOVA results also indicate that cereal rye termination and volumetric soil water content were different for factors YEAR, WEEK of evaluation, and TRT (rolling treatments: rolled/crimped and standing cereal rye as the control). Termination rates for variable SOIL were not significantly different $(p$-value $=0.3493)$. In contrast, VMC with respect to variable SOIL was significantly different ( $p$-value $<0.0001)$ due to different soil properties (Table 3$)$. Because of these highly significant differences and YEAR by TRT significant interactions, data for cereal rye termination rates and VMC were analyzed separately for each year, week, rolling treatment, and soil type because of an association between cereal rye termination rates and soil VMC.

Table 3. Analysis of variance results for cereal rye termination rates (\%) and soil volumetric water content (VMC \%) during the three weeks of evaluation period.

\begin{tabular}{cccccc}
\hline \multirow{2}{*}{ Source } & $*$ & \multicolumn{2}{c}{ Cereal Rye Termination } & \multicolumn{2}{c}{ Volumetric Water Content } \\
\cline { 3 - 6 } & & $\boldsymbol{p}$-Value & $\operatorname{Pr}>\mathbf{F}$ & $\boldsymbol{p}$-Value & $\operatorname{Pr}>\mathbf{F}$ \\
\hline REP & 2 & 0.89 & 0.4158 & 0.78 & 0.4619 \\
WEEK & 2 & 144.74 & $<0.001$ & 23.76 & $<0.001$ \\
SOIL & 1 & 0.88 & 0.3493 & 37.58 & $<0.001$ \\
TRT & 1 & 1219.16 & $<0.001$ & 30.70 & $<0.001$ \\
YEAR & 2 & 3.57 & 0.0322 & 45.93 & $<0.001$ \\
YEAR*TRT & 2 & 15.76 & $<0.001$ & 4.60 & 0.0125 \\
\hline
\end{tabular}

* DF (Degrees of Freedom). YEAR*TRT means YEAR by TREATMENT interaction.

Cereal rye termination rates (Table 4) were significantly higher at 3 weeks after rolling compared to one and two weeks after rolling. Standing rye had termination rates much lower than rolled rye residue for both soils. Figure $6 \mathrm{~B}$ has shown rolling and crimping cereal rye cover crop at the early milk growth stage utilizing a patented powered roller/crimper powered by BCS walk behind tractor.

Table 4. Termination rates for cereal rye during three weeks of evaluation for two soil types. Same lower-case letters (clay soil) and upper-case letters (sandy loam) indicate no differences between rolled and standing rye at $\alpha=0.10$.

\begin{tabular}{|c|c|c|c|c|c|c|c|c|c|c|}
\hline \multirow{4}{*}{ Soil Type } & \multirow{4}{*}{ TRT } & \multicolumn{9}{|c|}{ Growing Season } \\
\hline & & \multicolumn{3}{|c|}{2017} & \multicolumn{3}{|c|}{2018} & \multicolumn{3}{|c|}{2019} \\
\hline & & \multicolumn{9}{|c|}{ Days after Rolling/Crimping } \\
\hline & & 7 & 14 & 21 & 7 & 14 & 21 & 7 & 14 & 21 \\
\hline \multirow{4}{*}{$\begin{array}{c}\text { Clay } \\
\text { soil }\end{array}$} & Rolled & $51 a^{*}$ & $88 \mathrm{a}$ & $96 a$ & $55 a$ & $67 a$ & $96 a$ & $53 a$ & $81 \mathrm{a}$ & $92 a$ \\
\hline & Contr. & $16 \mathrm{~b}$ & $19 b$ & $24 \mathrm{~b}$ & $18 \mathrm{~b}$ & $37 \mathrm{~b}$ & $53 b$ & $15 b$ & $28 \mathrm{~b}$ & $40 \mathrm{~b}$ \\
\hline & $p$-value & 0.0163 & 0.0019 & 0.0003 & 0.0123 & 0.0117 & 0.0278 & 0.0037 & 0.0276 & 0.0003 \\
\hline & LSD & 13.4 & 8.85 & 3.72 & 11.97 & 11.77 & 21.15 & 6.77 & 26.4 & 2.48 \\
\hline \multirow{4}{*}{ Sandy loam } & Rolled & $60 a$ & $90 \mathrm{a}$ & $97 a$ & $61 \mathrm{a}$ & $69 a$ & $95 a$ & $52 a$ & $82 a$ & $93 a$ \\
\hline & Contr. & $15 b$ & $22 \mathrm{~b}$ & $24 \mathrm{~b}$ & $16 \mathrm{~b}$ & $19 b$ & $40 \mathrm{~b}$ & $24 \mathrm{~b}$ & $44 \mathrm{~b}$ & $49 \mathrm{~b}$ \\
\hline & $p$-value & 0.0021 & 0.0028 & 0.0003 & 0.0041 & 0.0079 & 0.0015 & 0.0424 & 0.0025 & 0.0479 \\
\hline & LSD & 6.03 & 10.60 & 3.81 & 8.42 & 13.07 & 6.21 & 17.39 & 5.60 & 29.87 \\
\hline
\end{tabular}

In each growing season, rolling was applied early spring (April) when the rye was at the milk growth stage (Zadoks growth stage $=75 ;[20]$ ) which is an optimum growth stage for mechanical termination of rye [2]. Cereal rye termination results are shown in Table 3. Across three growing seasons and evaluation period (one, two and three weeks after rolling), consistently higher termination rates were obtained for rolled residue compared to the standing rye control $76.6 \%$ vs. $27.3 \%$. On clay soil, the powered roller/crimper generated rye termination rates (averaged over growing seasons) 
of $53.1 \%, 78.9 \%$ and $94.8 \%$, one, two and three weeks after rolling compared to $16.4 \%, 28.1 \%$, and $36.2 \%$ obtained by the standing cereal rye. Similar termination rates were found for Sandy loam soil for which the powered roller/crimper generated termination rates $57.7 \%, 80.1 \%$ and $94.7 \%$ compared to $18.2 \%, 28.0 \%$ and $36.7 \%$ for standing cereal rye, one two and three weeks after rolling, respectively. Comparing termination rates from this experiment, the powered roller/crimper generated comparable termination rates obtained by larger heavy rollers crimpers [3,5]. Previous field experiments conducted by Kornecki et al. [5] with different larger rollers/crimpers (1.8 $\mathrm{m}$ wide), indicated that one week after rolling termination rates were below $20 \%$, and at second week after rolling were $40.9 \%, 38.5 \%$ and $44.6 \%$ for a standard straight bar, curved bar, and smooth roller with crimping arm, respectively. At three weeks after rolling these rollers had respective termination rates of $90.8 \%, 90.0 \%$ and $93.4 \%$. For two large heavy rollers (straight and experimental smooth roller with crimping arm, $4.1 \mathrm{~m}$ wide) generated average termination rates of $30.3 \%$ and $95.3 \%$, two and three weeks after rolling, respectively. In another field experiment, Kornecki et al. [25] reported that a heavy experimental $1.8 \mathrm{~m}$ wide roller crimper generated termination rates $81.0 \%, 93.3 \%$ and $97.8 \%$, one, two and three weeks after rolling, respectively. However, cereal rye termination was performed at later rye maturity: soft dough stage (Zadocks growth stage $=85$, [20]).

\subsection{Soil Volumetric Moisture Content}

Significantly different VMC with respect to YEAR ( $p$-value $<0.0001)$ was associated with different weather conditions, participation in each growing season. Overall, rolled cereal rye provided better soil moisture conservation one, two, and three weeks after rolling compared to standing rye (Table 5). VMC averaged across years, weeks, and soils was significantly higher $(13.2 \%)$ for rolled rye residue ( $p$-value $<0.0001)$ compared to lower VMC $(10.3 \%)$ for the control (standing rye). Data indicate that rolled rye residue provided better soil protection due to mulching effect (by creating uniform mat) and higher holding water capacity than the control standing rye. Uncovered soil with standing rye caused higher evaporation due to spacing between plants and higher evapotranspiration of still living plants.

Table 5. Volumetric soil moisture content (\%) after cereal rye termination in 2017-2019.

\begin{tabular}{|c|c|c|c|c|c|c|c|c|c|c|}
\hline \multirow{4}{*}{ Soil Type } & \multirow{4}{*}{ Treatment } & \multicolumn{9}{|c|}{ Growing Season } \\
\hline & & \multicolumn{3}{|c|}{2017} & \multicolumn{3}{|c|}{2018} & \multicolumn{3}{|c|}{2019} \\
\hline & & \multicolumn{9}{|c|}{ Days after Rolling/Crimping } \\
\hline & & 7 & 14 & 21 & 7 & 14 & 21 & 7 & 14 & 21 \\
\hline \multirow{4}{*}{$\begin{array}{c}\text { Clay } \\
\text { soil }\end{array}$} & Rolled & $18.7 a^{*}$ & $23.2 \mathrm{a}$ & $13.2 \mathrm{a}$ & $14.6 \mathrm{a}$ & $13.1 \mathrm{a}$ & $8.9 a$ & $14.1 \mathrm{a}$ & $13.4 \mathrm{a}$ & $15.9 a$ \\
\hline & Contr. & $14.2 \mathrm{~b}$ & $21.3 a$ & $11.3 b$ & $12.4 \mathrm{~b}$ & $11.4 \mathrm{~b}$ & $7.8 \mathrm{a}$ & $8.7 \mathrm{~b}$ & $9.0 \mathrm{~b}$ & $9.5 b$ \\
\hline & $p$-value & 0.0188 & 0.2421 & 0.0295 & 0.0549 & 0.0651 & 0.3526 & 0.0800 & 0.0333 & 0.0307 \\
\hline & LSD & 1.8 & N/S & 1.0 & 1.6 & 1.4 & $\mathrm{~N} / \mathrm{S}$ & 4.7 & 2.4 & 3.3 \\
\hline \multirow{4}{*}{ Sandy loam } & Rolled & $16.3 \mathrm{a}$ & $18.4 \mathrm{a}$ & $8.9 a$ & $13.7 \mathrm{a}$ & $9.2 \mathrm{a}$ & $4.3 a$ & $11.5 \mathrm{a}$ & $8.3 a$ & $12.0 \mathrm{a}$ \\
\hline & Contr. & $13.4 \mathrm{~b}$ & $17.8 \mathrm{a}$ & $7.3 b$ & $12.1 \mathrm{~b}$ & $8.0 \mathrm{~b}$ & $3.9 \mathrm{a}$ & $4.9 \mathrm{~b}$ & $5.1 b$ & $7.1 \mathrm{~b}$ \\
\hline & $p$-value & 0.0612 & 0.7452 & 0.0579 & 0.0488 & 0.0050 & 0.7490 & 0.0070 & 0.0260 & 0.0493 \\
\hline & LSD & 2.2 & N/S & 1.2 & 1.1 & 0.3 & N/S & 1.6 & 1.6 & 3.3 \\
\hline
\end{tabular}

* Treatment means followed by the same lowercase letters within each column for each soil type are not significantly different according to Fisher's Least Significant Difference Test ( $\alpha=0.10)$. N/S (non-significant).

Comparing two soil types, the VMC for clay soil was significantly higher $(15.0 \%$ for rolled and $11.7 \%$ for standing rye) than for sandy loam ( $11.4 \%$ for rolled and $8.8 \%$ for standing rye); $p$-value $<0.0001)$. Lower VMC for sandy soil is most likely associated with lower water holding capacity, higher infiltration rate, higher porosity compared with clay soil. These results are consistent with many different field studies $[5,15,25,26]$ and indicate that rolling/crimping operation utilizing a unique low weight powered roller/crimper for walk behind tractor, not only generated an effective termination for cereal rye and also provided measurable benefits in increasing soil water holding capacity compared to not rolling the cover crop. 


\subsection{Tomato Spacing, Tomato Plant Density, Tomato Yield and Number Fruit per Plant}

ANOVA results indicate that factor YEAR was highly significant that variables: number fruit per plant, tomato spacing and tomato yield (Table 6). In addition, number of fruit per plant was also dependent on SOIL. Because of these significant differences, data for each dependent variable were analyzed separately for each year, and the number of fruit per plant was analyzed by the soil type.

Table 6. Analysis of variance results for number of tomato fruit per plant, tomato spacing in a row and tomato yield.

\begin{tabular}{cccccccc}
\hline \multirow{2}{*}{ Source } & \multirow{2}{*}{ DF } & \multicolumn{2}{c}{ Tomato Fruit per Plant } & \multicolumn{2}{c}{ Tomato Spacing } & \multicolumn{2}{c}{ Tomato Yield } \\
\cline { 3 - 7 } & & $\boldsymbol{p}$-Value & $\boldsymbol{P r}>\mathbf{P}$ & $\boldsymbol{p}$-Value & $\operatorname{Pr}>\mathbf{P}$ & $\boldsymbol{p}$-Value & $\operatorname{Pr}>\mathbf{P}$ \\
\hline YEAR & 2 & 26.97 & $<0.001$ & 6.28 & 0.0171 & 8.81 & 0.0062 \\
BLOCK & 2 & 2.11 & 0.1714 & 0.20 & 0.8255 & 1.48 & 0.2735 \\
SOIL & 1 & 3.46 & 0.0924 & 0.05 & 0.8202 & 2.97 & 0.1154 \\
\hline
\end{tabular}

* Degrees of freedom.

Over three growing seasons, tomato spacing was varied among the growing seasons $(p$-value $=0.0171)$ but was not different between soils $(p$-value $=0.8202)$. Likewise, marketable tomato yield was different among growing seasons $(p$-value $=0.0062)$ but was not different between soil type $(p$-value $=0.1154)$. The number of tomato fruit yield per plant differed among growing seasons ( $p$-value $<0.0001)$, and was different between soils $(p$-value $=0.0924)$. These differences were most likely related to different growing conditions at each growing season.

\subsubsection{In-Row Tomato Spacing}

In 2017, tomato spacing was $57.9 \mathrm{~cm}, 60.6$ and $61.0 \mathrm{~cm}$ without significant differences among replications ( $p$-value $=0.2329$ ) and averaged $59.8 \mathrm{~cm}$. For clay soil the spacing was $59.0 \mathrm{~cm}$ and for sandy loam it was $60.7 \mathrm{~cm}$ without difference between soils ( $p$-value $=0.2605)$. In 2018 and 2019 no difference in tomato spacing was reported between these years having $73.7 \mathrm{~cm}$ and $70.9 \mathrm{~cm}$, respectively. In 2018 no difference in spacing between soil was reported ( $p$-value $=0.4777)$, spacing for clay was numerically higher $(78 \mathrm{~cm})$ compared to sandy loam $(69.0 \mathrm{~cm})$. No difference in spacing with respect to replications was detected ( $p$-value $=0.8239$ ) having $69.4 \mathrm{~cm}, 73.9$ and $77.9 \mathrm{~cm}$, and it was significantly smaller compared to larger spacing of $73.7 \mathrm{~cm}$ and $70.9 \mathrm{~cm}$ in 2018 and 2019, respectively (Table 7). Likewise, in 2019 no difference in spacing between soils was found ( $p$-value $=0.4176$ ) with $68 \mathrm{~cm}$ for clay soil and $73.4 \mathrm{~cm}$ for sandy loam. Similarly, no difference in spacing was reported among replications $(p$-value $=0.7170)$ getting $67.8 \mathrm{~cm}, 71.7 \mathrm{~cm}$ and $73.1 \mathrm{~cm}$. Above results indicate the transplanter did performed well keeping spacing fairly uniform; some numerical differences were related to necessity of changing forward working speed to obtain good transplanting quality into flattened rye residue cover.

Table 7. Tomato in-row spacing, tomato plant density per ha, tomato yield and number of fruits per each tomato plant.

\begin{tabular}{|c|c|c|c|c|c|c|}
\hline Growing Season & $\begin{array}{c}\text { Tomato } \\
\text { Spacing } \\
\text { (cm) }\end{array}$ & $\begin{array}{c}\text { Tomato Plant Density } \\
\text { Plants ha }\end{array}$ & Yield Mg ha ${ }^{-1}$ & $\begin{array}{l}\text { Number Fruits/Plant } \\
\text { for Variable YEAR }\end{array}$ & \multicolumn{2}{|c|}{$\begin{array}{l}\text { Number Fruits/Plant } \\
\text { for Variable SOIL }\end{array}$} \\
\hline 2018 & $73.7 \mathrm{a}$ & $4650 b$ & $28.3 a$ & $15 b$ & Clay soil & $16 a$ \\
\hline 2019 & $70.9 a$ & $5197 a$ & $25.3 a$ & $20 \mathrm{a}$ & \multirow{2}{*}{$\begin{array}{l}\text { Sandy } \\
\text { loam }\end{array}$} & \multirow{2}{*}{$13 b$} \\
\hline$p$-value & 0.0171 & 0.0134 & 0.0062 & $<0.0001$ & & \\
\hline Average & 68 & 5124 & 23.2 & 14 & Average & 14 \\
\hline
\end{tabular}

* Treatment means followed by the same lowercase letters within each column for each growing season and soil type are not significantly different according to Fisher's Least Significant Difference Test $(\alpha=0.10)$. 


\subsubsection{Tomato Plant Density}

For Davidson clay soil, an average tomato plant density over three growing seasons was 5143 plants ha ${ }^{-1}$. There was a significant difference in tomato plant density among growing seasons $(p$-value $=0.0331)$ with lower density of 4158 plants ha $^{-1}$ in 2018 to high density of 5799 plants ha $^{-1}$ in 2017. In 2019 the plants density was 5417 plants ha ${ }^{-1}$ without difference to 2017. Similar average plant density was reported for Hiwassee sandy loam with 5106 plants $\mathrm{ha}^{-1}$. There was no significant difference in tomato plant density among growing seasons ( $p$-value $=0.2844)$, however, the density was numerically lower in 2019 (4924 plants ha ${ }^{-1}$ ) compared to 5252 plants ha $^{-1}$ in 2017 and 5142 plants ha $^{-1}$ in 2018 (Table 7).

To evaluate the performance of the transplanter, the first gear of the BCS 583 two-wheel tractor was employed with the no-till transplanter to transplant tomato seedlings. The average working speed of the transplanter was $1.1 \mathrm{~km} \mathrm{~h}^{-1}$. At this speed and spacing between rows of $1.0 \mathrm{~m}$, the field efficiency was $0.11 \mathrm{ha} \mathrm{h}^{-1}$. Consequently, it would require $9 \mathrm{~h}$ to transplant tomato seedlings on the one-hectare land area with cover crop residue. By comparison, hand transplanting efficiency would be about $60 \mathrm{~m}^{2}$ per hour (personal communications), or it would require $163 \mathrm{~h}$ to transplant tomato on one hectare, which was 18 times slower than results obtained in this experiment utilizing a no-till transplanter.

\subsubsection{Tomato Yield}

No significant difference in tomato yield found between soils ( $p$-value $=0.1154$ ). Numerically higher tomato yield was reported for clay soil (25.3 $\left.\mathrm{Mg} \mathrm{ha}^{-1}\right)$ compared to sandy loam $\left(21.0 \mathrm{Mg} \mathrm{ha}^{-1}\right)$. Higher weed pressure on sandy loam associated with lower biomass rye residue cover, lower water holding capacity and larger insect infestation was most likely reason for generating numerically lower tomato yield compared with clay soil. Tomato yield varied among the growing seasons ( $p$-value $=0.0062)$ with the significantly lower yield in $2017\left(15.9 \mathrm{Mg} \mathrm{ha}^{-1}\right)$, compared with higher yield obtained in $2018\left(28.3 \mathrm{Mg} \mathrm{ha}^{-1}\right)$ and in $2019\left(25.3 \mathrm{Mg} \mathrm{ha}^{-1}\right)$ without significant differences between 2018 and 2019 growing seasons (Table 7). Main reason for these differences was the initial smaller in-row plant spacing in $2017(59.8 \mathrm{~cm})$ compared to larger spacing of $73.7 \mathrm{~cm}$ in 2018 , and $70.9 \mathrm{~cm}$ in 2019.

\subsubsection{Number of Fruits per Plant}

Across all growing seasons and soil types an average number of tomato fruit per plant was 14. Significant difference in number of produced fruits per each tomato plant was observed among growing seasons ( $p$-value $<0.0001)$ with the lowest number of fruits (8 fruit per plant) compared to higher 15 fruits per plant in 2018, and compared to the highest number of fruits per plant (20 fruit) in 2019. Likewise, there was a significant difference in number fruits per plant between soil types $(p$-value $=0.0910)$ with higher number tomato fruits per plant (16 fruit) for clay soil compared to lower number fruit per plant (13 fruit) for sandy loam soil (Table 7).

\section{Conclusions}

Widespread adoption of conservation farming systems in small US farms are hindered by lack of small machineries for no-till drilling, crimping cover crops and no-till transplanting. To help small farms reduce hand labor and adoption of conservation systems with cover crops, no-till equipment such as a no-till drill, powered roller/crimper, and no-till transplanter have been developed for walk-behind tractors at the USDA, NSDL. We hypothesized that the system performance of this set of three machines will be robust.

Overall, data from this field experiment during three growing seasons indicated that an active coulter no-till drill successfully planted cereal rye. Biomass production was at levels as normally encountered by heavy no-till drills. In each growing season, the powered roller crimper consistently generated high rye termination rates without herbicides. Termination rates averaged over growing 
seasons and soils were 55\%, $80 \%$ and $95 \%$ compared with the control (standing rye) generating $17 \%, 28 \%$ and $38 \%$ termination rates, one, two, and three weeks after rolling. The automatic no-till transplanter operated as expected without any mechanical problems and exceeded $90 \%$ of uniformity for transplanted tomato seedlings. Higher tomato yield on Davidson clay might be associated with less insect/pathogen pressure, higher plant available water and reduced weeds pressure due to greater cereal rye biomass production. Overall, no-till equipment tested in this research is a viable solution to help small farming community to relieve heavy labor while implementing conservation agriculture in their farming operation as a sustainable system. Conservation agriculture machinery for small farms is a valuable contribution to existing literature where most studies are conducted for big commercial agriculture enterprises.

The limitation of this study is the test was conducted only for rye as cover crop with tomato as the main crop. In addition, for adoption, the fixed cost in purchasing the system needs to be accounted. For future directions, we intend to test the system using other cover crops, cost the system, identify potential machinery manufacturers who will commit in manufacturing and selling the machines, and reach out to global partners in Southeast Asia where walk-behind tractors are commonly practiced and evaluate the applicability of this set of three machines system in tropical conditions.

Author Contributions: T.S.K. and M.R.R. collaborated on experimental conceptualization, experimental investigation, contributing to resources, statistical analysis, and writing-original draft preparation. All authors have read and agreed to the published version of the manuscript.

Funding: This research received funding from the USDA-Agricultural Research Service.

Acknowledgments: The authors wish to acknowledge Corey Kichler, Agriculture Engineer at the USDA-ARS, NSDL, Auburn, AL for his personal involvement in equipment design and fabrication, cover crop planting/termination and transplanting tomato seedlings. In addition, the authors are acknowledging the Sustainable Intensification Innovation Lab, Kansas State University for opening the tests of USDA-ARS, NSDL designed machines in Cambodia that led to this publication partnership. The authors envision that testing methodologies of small conservation agriculture machines in Cambodia and in other Southeast Asian country partners will be patterned after this publication.

Conflicts of Interest: The authors declare no conflict of interest.

\section{References}

1. Reeves, D.W. Cover Crops and Rotations. In Advances in Soil Science: Crops Residue Management; Hatfield, J.L., Stewart, B.A., Eds.; Lewis Publishers: Boca Raton, FL, USA, 1994; pp. 125-172.

2. Nelson, J.E.; Kephart, K.D.; Bauer, A.; Connor, J.F. Growth Stage of Wheat, Barley, and Wild Oat; University of Missouri Extension Service: Columbia, MO, USA, 1995; pp. 1-20.

3. Kornecki, T.S.; Price, A.J. Effects of different roller/crimper designs and rolling speed on rye cover crop termination and seedcotton yield in a no-till system. J. Cotton Sci. 2011, 14, 212-220.

4. Ashford, D.L.; Reeves, D.W. Use of a mechanical roller crimper as an alternative kill method for cover crop. Am. J. Altern. Agric. 2003, 18, 37-45. [CrossRef]

5. Kornecki, T.S.; Price, A.J.; Raper, R.L. Performance of different roller designs in terminating rye cover crop and reducing vibration. Appl. Eng. Agric. 2006, 22, 633-641. [CrossRef]

6. Derpsch, R.; Friedrich, T.; Kassam, A.; Hongwen, L. Current status of adoption of no-till farming in the world and some of its main benefits. Int. J. Agric. Biol. Eng. 2010, 3, 1-25. [CrossRef]

7. Hargrove, W.L.; Frye, W.W. The Need for Legume Cover Crops in Conservation Tillage Production. In The Role of Legumes in Conservation Tillage Systems; Power, J.F., Ed.; Soil and Water Conservation Society of America: Ankeny, AI, USA, 1987; pp. 1-5.

8. Barnes, J.P.; Putnam, A.R. Rye residues contribute weed suppression in no-tillage cropping systems. J. Chem. Ecol. 1983, 9, 1045-1057. [CrossRef]

9. Blough, R.F.; Jarrett, A.R.; Hamlett, J.M.; Shaw, M.D. Runoff and erosion water from silt, conventional, and chisel tillage under simulated rainfall. Trans. ASAE 1990, 33, 1557-1562. [CrossRef]

10. Mahboubi, A.A.; Lal, R.; Faussey, N.R. Twenty-eight years of tillage effects on two soils in Ohio. Soil Sci. Soc. Am. J. 1993, 57, 506-512. [CrossRef] 
11. Abdul-Baki, A.A.; Teasdale, J.R.; Korcak, R.; Chitwood, D.J.; Huettel, R.N. Fresh-market tomato production in a low-input alternative system using cover crop mulch. HortScience 1996, 31, 65-69. [CrossRef]

12. Edralin, D.A.; Sigua, G.C.; Reyes, M.R.; Mulvaney, M.J.; Andrews, S.S. Conservation agriculture improves yield and reduces weeding activity in sandy soils of Cambodia. Agron. Sustain. Dev. 2017, 37, 52. [CrossRef]

13. Assefa, T.; Jha, M.; Reyes, M.; Tilahun, S.; Worqlul, A.W. Experimental Evaluation of Conservation Agriculture with Drip Irrigation for Water Productivity in Sub-Saharan Africa. Water 2019, 11, 530. [CrossRef]

14. Paudel, S.; Sah, L.P.; Devkota, M.; Poudyal, V.; Prasad, P.V.; Reyes, M.R. Conservation Agriculture and Integrated Pest Management Practices Improve Yield and Income while Reducing Labor, Pests, Diseases and Chemical Pesticide Use in Smallholder Vegetable Farms in Nepal. Sustainability 2020, 12, 6418. [CrossRef]

15. Kornecki, T.S. Rye termination by different rollers/crimpers developed for no-till small-scale farms. Appl. Eng. Agric. 2015, 31, 849-856. [CrossRef]

16. Kornecki, T.S.; Kichler, C.M. Active Coulter Planting System. U.S. Patent 2016/0088786 A1, 31 March 2016.

17. Kornecki, T.S. Powered Rolling and Crimping Device for Crop Termination. U.S. Patent No. 8,176,991 B1, 15 May 2012.

18. Kornecki, T.S.; Kichler, C.M. Transplanter for a Walk-Behind Tractor. U.S. Patent No. 10,004,174 B2, 26 June 2018.

19. Grieve Ovens \& Furnaces. Available online: https://www.grievecorp.com/product-category/shelf-loadingovens/shelf-ovens/ (accessed on 21 November 2020).

20. Zadoks, J.C.; Chang, T.T.; Konzak, C.F. A decimal code for the growth stages of cereals. Weed Res. 1974, 14, 415-421. [CrossRef]

21. Kornecki, T.S.; Arriaga, F.J.; Price, A.J. Evaluation of methods to assess termination rates of cover crops using visual and non-visible light active sensors. Trans. ASABE 2012, 55, 733-741. [CrossRef]

22. Steel, R.G.D.; Torrie, J.H. Principles and Procedures of Statistics. A Biometrical Approach, 2nd ed.; McGraw-Hill Publishing Co.: New York, NY, USA, 1980.

23. Gomez, K.A.; Gomez, A.A. Statistical Procedures for Agricultural Research, 2nd ed.; John Wiley \& Sons, Inc.: New York, NY, USA, 1984.

24. SAS. Proprietary Software Release 9.2; SAS Institute, Inc.: Cary, NC, USA, 2013.

25. Kornecki, T.S.; Price, A.J.; Raper, R.L.; Bergtold, J.S. Effectiveness of different herbicide applicators mounted on a roller/crimper for accelerated rye cover crop termination. Appl. Eng. Agric. 2009, 25, 819-826. [CrossRef]

26. Kornecki, T.S.; Price, A.J. Management of High-Residue Cover Crops in a Conservation Tillage Organic Vegetable On-Farm Setting. Agronomy 2019, 9, 640. [CrossRef]

Publisher's Note: MDPI stays neutral with regard to jurisdictional claims in published maps and institutional affiliations.

(C) 2020 by the authors. Licensee MDPI, Basel, Switzerland. This article is an open access article distributed under the terms and conditions of the Creative Commons Attribution (CC BY) license (http://creativecommons.org/licenses/by/4.0/). 